\title{
METHODOLOGY OF PROBLEMS CREATION AND SELECTION FOR ASTRONOMY OLYMPIADS ON EXAMPLE OF TASKS ON THE TOPIC OF KEPLER'S LAWS
}

\author{
YaROSLAV ERSTENIUK, IVAN GASYUK, PETRO YAKUBOVSKYI, ANNA BORYSCHAK
}

\begin{abstract}
Based on many years of experience in the organization of the third stage of Ukrainian National Astronomy Olympiad, the authors of the article attempt to formulate general principles for the selection and compilation of astronomy olympiad problems, as well as to demonstrate the application of the described principles on the example of astronomy olympiads in Ivano-Frankivsk region.

The peculiarities of school Olympiad in astronomy, the purpose of their conduct, the specificity of task packages, including necessity for differentiation by complexity and topics, were analyzed. A characteristic feature of the Olympiad tasks is their non-standard nature, necessity to use methods that are unusual for students to solve problems. On the other hand, such tasks should match intellectual development of the competition participants, and the course of the solution should be accessible to understanding and should not require knowledge of a university program. In particular, on the basis of the analysis by the authors of the process of compiling astronomy Olympiad tasks, which were offered to students in the past years at the regional stage of the student Olympiads, were identified, the methods of their creation were systematized and characterized. Each method contains a detailed explanation, justification for its use and examples, both analytical and practical. For the sake of clarity, the topic "Kepler Laws" was choosen for Olympiad problems, which were analyzed and methods used to create them were described. This topic is one of the fundamental in the schoolar astronomy, which determines both the need to include such tasks in the Olympiad program and the complexity of their choice, and creation, because the topic is narrow enough and is qualitatively covered in various textbooks and collections of problems.
\end{abstract}

Keywords: Olympiad tasks, Ukrainian National Astronomy Olympiad, Kepler's laws.

\section{INTRODUCTION}

Traditionally, a school student subject Olympiads is a general measure aimed at stimulating the attraction of individual students to self-education, updating their interest in studying the subject, forming the initial research skills of a future scientist. An analysis of the process of organizing such competitions at school district, city, or regional levels over the years has shown that the problems that arise from this are largely determined by the overly formalized approach of the organizers or subject teachers, the overload of some participants in competitions in multiple subjects over one year, 
insufficient attention to the preparation of the psychological state of children (lack of thier understanding of expediency to participate in the competition and the benefit of additional training in the subject).

Objective: To explore and formulate tasking principles for Ukrainian National Astronomy Olympiad.

One of the main factors for the success of the National Olympiad at different levels is the adequacy of the selection of tasks of the so-called "Olympiad type", the content of which formulation and approaches to the solution should, on the one hand, not go outside the program, and on the other contain non-standard, not spelled out in textbooks, elements of approaches to their interpretation or resolution. Of course, the characteristic of the content of the Olympiad tasks is determined by the course and may contain certain elements, depending on the purpose that the author group defines. In this perspective, the subject of the Olympiad in Astronomy is particularly noteworthy. This is due to several features of studying a discipline in a school course.

1. Astronomy as a school subject is usually studied only in the final grades of a comprehensive school. In addition, the number of academic hours allocated to the study of astronomy is very limited. Such factors do not contribute at all to the good learning of the students of the discipline, and the preparation of children for the Olympiad should be conducted in the framework of group work or individual events outside the school curriculum.

2. As experience shows, it is irrational to divide Olympiad participants by classes at school. It is possible to separate the maximum into two groups (senior and junior), formed by the level of training in related subjects (physics, mathematics and geography).

3. In the design of tasks, unlike approaches in the organization of the Olympiad from other disciplines, it is not possible to be guided by the principle of conformity of the content of the tasks with the passed stage of studying the material of the discipline. Thus, the consent of the participants of the Olympiad and their leaders is necessary to solve the task of a level that is much higher than the material of the school discipline. In the case of junior pupils participating in the Olympiad, such material is not studied at all at official lessons.

4. In comparison with other subjects, the astronomical Olympiad movement has a rather short history, which determines the weak level of material and educational base, in particular the lack of literature, including scientific publications, aimed at improving the skills and knowledge of teachers, training of students, etc.

In view of the above arguments, astronomical Olympiads require careful study and development of methods for their conduct.

Despite the efforts of individual domestic and foreign educators, scientists and methodologists (I. Klymyshyn, S. Kuzjmenkov, I. Sokol, A. Buryj, B. Voroncov-Veljjaminov, M. Daghajev, A. Sule, M. Sandu etc.) an important characteristic of astronomy Olympiads in connection with the short history of their conduct is a small amount of literature for the preparation of students.

Much worse is the situation with scientific publications and methodological support for astronomical Olympiads: only a few works are available on this topic. In particular, in the article by S. Malchenko an attempt was made to carry out a general analysis of problems, but the described approach has no clear application in the compilation of astronomical Olympiads [1]. I. Pustynnykova, Ju. Kucher, A. Stavsjka conducted an analysis of the evaluation of the Olympiad tasks [2].

According to the team of authors, the works of the Romanian scientist M. Sandu, especially in [3], where the in-depth presentation of theoretical material on astronomy in the context of the Olympiads is conducted, as well as examples of particularly complex problems with detailed descriptions and explanations are extremely useful for the methodological support of the Olympiads. 


\section{ANALYSIS AND DisCUSSION}

\subsection{THE COMPLEXITY OF THE OLYMPIAD PROBLEMS}

The task package for school astronomy Olympiad should be differentiated in complexity, that is, contain both basic level tasks, medium and high complexity tasks. This is due to the goals that the organizers of the student Olympiads face, because the event must fulfill the following tasks:

- stimulate creative self-improvement of children, student youth;

- identify and develop gifted students, assist them in choosing a profession, involve them in higher education;

- realize the abilities of talented students;

- increase interest in in-depth study of educational, special and professional disciplines, to develop in the circles of students youth research skills;

- promote the achievements of science and the latest technologies etc. [4]

Thus, the simple, basic tasks included in the package are aimed at strengthening students' selfesteem and preventing the loss of interest in the study of astronomy. It should be noted that the tasks of this class should include, except classical and template problems, simple non-standard tasks for logic and general erudition. Such tasks can be both purely astronomical or belong to related disciplines. At the same time, it is not necessary to be limited only to physical tasks; however, geography, chemistry and mathematics are related to astronomy as well.

To stimulate students' creative self-improvement, it is also necessary to include mid-complexety tasks that require a high level of knowledge of basic models and laws, the limits of their application, knowledge of effects, creative thinking. These tasks should be simple for well-prepared students and encourage less-prepared students to study further. Also, such problems are intended for grading student achievement and identifying winners.

Equally important is the inclusion in the Olympiad of a high level of complexity - creative, nonstandard, multi-stage tasks, the solution of which should be based on the application of different laws, taking into account many effects, the use of unusual ways for students to solve and knowledge of other disciplines. These tasks are aimed primarily at realizing the abilities of talented students, determining the winners of the Olympiad. Such tasks should be selected in such a way that they can be solved by units or, even, no complete solution is given. It provides, on the one hand, the selection and stimulation of the interest of the most able and inquisitive students, provides an improvement in the level of knowledge of teachers and students, prevents stagnation in teaching and learning, and on the other, provides the main paradigm of the Olympiads: student evaluation is not on the principle of control work when assessing the correctness of the answer, and on the "idea" principle, when the most important in the problem is the idea of its solution, not its course and final answer. According to the team of authors, the application of the principle of control work (test) to the astronomy Olympiad is the main problem of such events at different levels. In this case, the winners are not the the most trained students with non-standard, creative thinking and sophisticated analytical skills, but the students who are the most proficient in calculations and can make a large amount of calculating with limited numbers of errors for a limited time. This contradicts the principles and objectives of the Ukrainian National Astronomy Olympiad as defined in [4,5].

It is possible to combine sub-items of varying complexity in a complex task. This approach is often used in the tasks of international Olympiads, in particular the International Olympiad in Astronomy and Astrophysics [6,7].

\subsection{THEME OF TASKS}

Letters from the Institute Of Education Content Modernization and the decree of the Ministry of Education and Science of Ukraine define the indicative list of theoretical questions which student Olympiad tasks should be based on, as well as recommendations for adhering to the subject and format of the previous Olympiad Olympiad, and a list of recommended literature [4;5]. 
A feature of astronomy among other disciplines is the relatively small number of topics provided for study. This defines the problem of composing and selecting non-standard tasks of medium and high complexity, and together with the lack of teaching astronomy to students before 11th grade determines the need to use knowledge of related disciplines and general erudition. Here again it should be emphasized that the problem of the modern Ukrainian National Astronomy Olympiad is a significant bias towards physics and neglect of the cross-cutting links with mathematics, geography and chemistry.

It is important to cover a variety of topics in order to encourage students to comprehensively study the discipline and related fields, which should ensure the full development of students participating in astronomy Olympiads. This rule is also confirmed by the statutes of international Olympiads, in particular, the statute of the International Olympiad in Astronomy and Astrophysics determines the need to use at least 4 sections of astronomy in the package of tasks [6]. However, some topics are basic in astronomy, which determines the need for their deep understanding of students. These include, for example, Kepler's laws, the daily motion of Earth, stellar magnitudes and photometry, telescopes and their characteristics, the redshift and the determination of distances to galaxies (for 11th grade students) and more. According to the team of authors, tasks on these topics should be included in each package. There are several problems with this.

The first is the limited size of the task package and the need for balance with other topics. The solution to this problem is complex problems, which need to be solved either by attracting knowledge on different topics, or those that consist of many diversified sub-topics.

The second problem is the considerable complexity of selecting non-standard and creative tasks on these topics. You can use the following methods to solve them. As an example, the topic of "Kepler's Laws", which is one of the fundamental in the school astronomy framework, was chosen to analyze the methods of problem-solving.

\subsection{Methods of Composing Non-STANDARd Astronomy Problems}

The author's classification of methods for compiling non-standard astronomy problems will be described below. At the same time, the tasks for convenience are presented separately, as some of them illustrate several principles at once.

\subsubsection{The Method of UnUSual AcCent}

The school course examines Kepler's laws as follows [8]:

1. Each of the planets moves around the Sun along an ellipse in one of the focuses of which is the Sun.

2. The radius vector of the planet at equal intervals grabs equal areas.

3. The squares of the sidereal periods of rotation of the planets around the sun are directly proportional to the cubes of the large axes of their orbits.

If the sidereal periods of rotation of two planets denote $T_{1}$ and $T_{2}$, and the large semi axesof the ellipses - respectively a1 and a2, then the third Kepler law is:

$$
\frac{T_{1}^{2}}{T_{2}^{2}}=\frac{a_{1}^{3}}{a_{2}^{3}}
$$

The students also study the generalized third Kepler law: if the sidereal periods of rotation of two planets denote $\mathrm{T}_{1}$ and $\mathrm{T}_{2}$, the large semi axesof the ellipses - respectively a1 and $\mathrm{a}_{2}$, and the masses of central bodies and their satellites - respectively $M_{1}$ and $M_{2}, m_{1}$ and $m_{2}$, then:

$$
\frac{\left(M_{1}+m_{1}\right) \cdot T_{1}^{2}}{\left(M_{2}+m_{2}\right) \cdot T_{2}^{2}}=\frac{a_{1}^{3}}{a_{2}^{3}}
$$


Students usually concentrate on Kepler's third law, with the other two getting undeservedly little attention. Thus, shifting the focus of the problem to using the properties of an ellipse (Kepler's first law) or comparing flight time by comparing squares (Kepler's second law) can make the task unusual and interesting.

Thus, to summarize, the basic idea behind this method is to use laws or principles that in other circumstances receive little attention

\subsubsection{METHOD OF DETAILS}

This method is partly similar to the unusual accent method, since the content of the material, which has received little attention, is the basis of the problem. However, in this case it is not a law, but a certain property or feature of a well-known law. These may be the limits of its application, specific details of its application under certain specific conditions, the unusual nature of submitting certain variables, etc. A good example is to provide data about the orbit parameters of system around its center of mass instead of the satellite orbit parameters around the central body. Thus, the detail is that the third Kepler law can be applied only to a reference system that is fixed to one of the objects of the system, and impossibility to apply it to the reference system connected to the center of mass.

\subsubsection{Method OF Neglection}

A feature of astronomy among other disciplines is low accuracy and a large number of approximations. You can introduce this feature by adding a task into a package to evaluate certain values. Typically, such tasks involve improving creative and non-standard thinking in order to create an idealized model for describing a phenomenon or process that rejects irrelevant details and focuses on the essence. Important in such tasks is to prove the feasibility of simplifications, to demonstrate their capabilities and to evaluate the error in calculations. An example of such assignments is the problem that involves the need to use the second Kepler law to estimate the value of the area grabbed by the radius-vector.

\subsubsection{COMPREHENSIVE METHOD}

The comprehensive method is one of the easiest ones in this list. It involves merging several, usually 3-5, classic and template tasks into one. However, the complexity of the tasks created by this method is based on the fact that the student needs to split one big problem into several subtasks that need to be solved separately, and then summarize the results for a common solution. Thus, the level of complexity of such tasks is determined by the apparent partitioning and the smoothness of transitions between subtasks.

\subsubsection{METHOD OF CONSEQUENCES}

According to the team of authors, the tasks accomplished by this method are extremely important, since solving them requires not only a thorough knowledge but also analytical and creative skills of the students. The problem is formulated in such a way that its solution is based on a non-standard consequence of the known law. Usually, the consequence is rather narrow in scope, that is, it is relevant only for a specific set of characteristics of the external or internal environment, or solves a very narrow problem, so that in other circumstances student do not pay attention to it. An example of such an effect on the topic "Kepler's laws" is the invariance of the dependence of the rotation period and the large semi axeson the ratio of body masses of the system. Therefore, it can be assumed that the transfer of mass from one body to another the rotation period and the large semi axeswill not change. It should be noted that this effect only acts when it is possible to neglect the mass of the substance, which is currently transmitted from one body to another, in comparison with the mass of the bodies of the system. 


\subsubsection{THE METHOD OF ANALOGIES}

Tasks made using this method use law, pattern, or theory that are familiar to students in one particular context, transferring its use to another, similar in content. Thus, students should draw an analogy between the phenomenon or process described in the problem and what is already known to them, identify common and distinguishing features, and use a known mathematical or physical model, law, or pattern based on it. An example of using this method is to give the task of changing the orbital period when the rate of change is known. Students, for example, may be asked to make and analogy with rectilinear motion and to determine the rotation period after a certain time based on known laws.

\subsubsection{METHOD OF NeW LAWS}

This method is intended to actualize and improve the analytical and creative abilities of students, and use elements of the subject unknown to the students. The condition of the problem must include a detailed description of model, law or hypothesis that underlies the solution of the problem, except for the moments that the student must reach to on the basis of principles known to him from the school course. Such tasks can be even simple if they only involve the use of the models, laws, or hypotheses described in practice. It should be borne in mind that some students, especially at the first stages of the Olympiad, may not even begin to solve the problem because of the long condition and the presence of unknown formulas in it. However, the team of authors considers it expedient to use such tasks at the III and IV stages of the student Olympiads.

\subsection{EXAMPLES OF TASKS ON THE THEME “KEPLER'S LAWS”}

The tasks described below have been offered to the participants of the stage III of the Ukrainian National Astronomy Olympiad in the Ivano-Frankivsk region for the last five years. Tasks are chosen to illustrate the above methods of constructing non-standard astronomy problems.

\subsubsection{Planet Nataly-1 and Its Satellite, Practical Problem at III Stage of the UKRAINIAN NATIONAL ASTRONOMY OLYMPIAD IN IVANO-FrANKIVSK REGION FOR $\mathbf{1 0}^{\mathrm{TH}}-\mathbf{1 1}^{\mathrm{TH}}$ GRADES STUDENTS, 2016}

The Figure 1 shows the trajectory of a satellite rotating around the planet Nataly-1. The mass of this planet is equal to the mass of the Earth $(6 \times 1024 \mathrm{~kg})$. The influence of the star around which Nataly-1 rotates should not be taken into account. The time during which a satellite flies the indicated particles of its orbit is equal to 20 minutes. The mass of the satellite is much smaller than that of Nataly-1. The area of the ellipse is $S=\pi a b$.

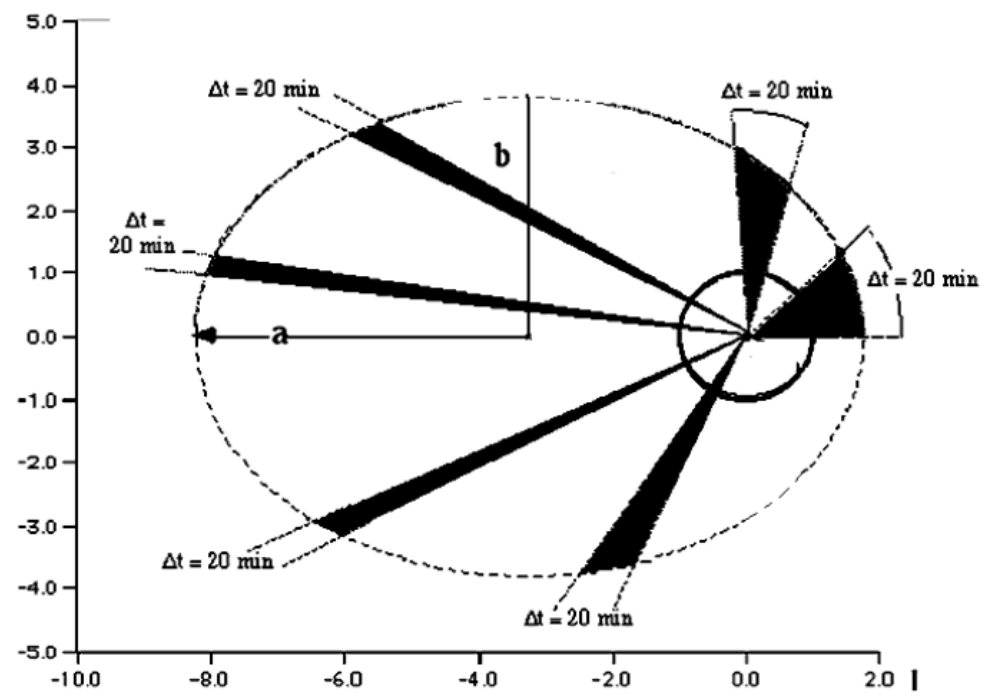

Fig. 1. Trajectory of a satellite rotating around the planet Nataly-1 
a) Estimate the eccentricity e of the satellite's orbit.

b) Estimate the period $\mathrm{T}$ of the satellite's rotation.

c) Evaluate the large semi axesand the orbits of the satellite.

d) Estimate the distance $r_{a}$ at the apocenter and $r_{p}$ at the perimeter of the satellite orbit.

e) Estimate the velocity $v_{a}$ at the apocenter and $v_{p}$ at the perimeter of the satellite orbit.

This task can be broadly attributed to the base, as subparagraphs (a), (c), and (d) are trivial and should not be difficult to students. Subparagraph (e) requires a deeper knowledge of the motion laws of the planet and the use of formulas for finding the velocity at the pericenter and apocenter, or the comprehensive application of Kepler's second law and the law of conservation of energy. However, the most interesting is subparagraph (b), the drafting of which used neglect and unusual accent methods. Finding the answer to this subparagraph requires the use of Kepler's second law, that is, estimating the area of one of the highlined parts of the satellite's orbit and comparing it to the total area of the ellipse. It is necessary to select the part of the ellipse in which the motion trajectory of the satellite is as close as possible to the straight line to reduce the error of area estimation.

\subsubsection{Abnormal Shift of Mercury Perihelion, Theoretical Problem at III Stage of the

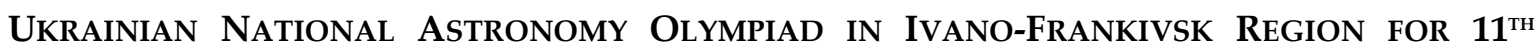 GRADE STUDENTS, 2017}

The anomalous shift of the Mercury perihelion - discovered in 1859 feature of the planet Mercury motion, which played an exceptional role in the history of physics. This shift was the first movement of a celestial body that did not obey Newton's law of gravity. Physicists have had to look for ways to modify or generalize the theory of gravity. The search was a success in 1915 when Albert Einstein developed a general theory of relativity. The exact solution of Einstein's equations, obtained by Karl Schwarzschild in January 1916, showed that the perihelion of the planets really must undergo additional displacement compared to Newtonian theory.

The additional displacement of the perihelion of the planet (in radians per revolution) in the general theory of relativity can be written by the formula:

$$
\delta \approx \frac{24 \pi^{3} a^{4}}{T^{2} c^{2} b^{2}}, \text { where }
$$

c - speed of light (300 $000 \mathrm{~km} / \mathrm{s})$;

$\mathrm{T}$ - rotation period of the planet around the Sun;

a - magnitude of the large semi axis of the planet orbit;

$\mathrm{b}$ - magnitude of the small semi axis of the planet orbit.

Mercury data:

$\begin{array}{ll}\text { Perihelion } & 46001200 \mathrm{~km} \\ 0,307499 \mathrm{a} . \mathrm{u} .\end{array}$

Aphelion

$69816900 \mathrm{~km}$

0,466697 a. u.

Based on the information provided:

a) determine the large semi axis of the orbit of Mercury;

b) determine the eccentricity of the orbit of Mercury;

c) determine the rotation period of Mercury around the Sun;

d) determine the small semi axis of the orbit of Mercury;

e) to determine the additional displacement of the perihelion of the orbit of Mercury per revolution (in radians);

e) to determine the additional displacement of the perihelion of Mercury's orbit per century (in radians); 
g) compare the value obtained in the previous subparagraph with the observed value $(43.1 \pm 0.5$ arcsec per century).

This problem illustrates the use of the method of new laws, because the condition introduces the concept of anomalous displacement of Mercury perihelion, gives a mathematical description of this phenomenon according to the general theory of relativity, and proposes to compare the calculated results with the observed value, as well as the method of unusual accents, which require knowing properties of the ellipse to determine small semi axis. To some extent, this task also illustrates the principle of complexity.

\subsubsection{XViI Century, Theoretical Problem at III Stage of the Ukrainian National ASTRONOMY OLYMPIAD IN IVANO-FRANKIVSK REgION FOR 10 10-11 $^{\mathrm{TH}}$ GRADES STUDENTS, 2019}

You sit down with a friend and have lunch discussing Newton's recently read Principia's treatise, in which he generalize Kepler's third law. Your friend said:

"Consider a system that consists of two celestial bodies. Let mass of the first body be 4 masses of the Sun, mass of the second body one mass of the Sun, and the distances from the common center of mass are 2 and 4 astronomical units, respectively. Then we have that period of rotation of the second planet around the common center of mass $\mathrm{T}=\sqrt{\frac{(4 \text { a.u. })^{3}}{4 \text { masses of the Sun }}}=4$ years."

Find and explain mistakes in a friend's reasoning.

This task illustrates the method of detail - it is based entirely on knowledge of the boundaries and conditions of application of the generalized third Kepler law. Although this law is generally well studied, details and limits of its application are rarely addressed. If we consider the solution of this problem, the errors are as follows:

1. The denominator of the formula must contain sum of the masses of the system objects.

2. The ratio of the distances to the center of mass must be inversely proportional to the mass of the objects.

3. The numerator of the formula must contain distance between the objects, but not to the center of mass.

Note: the formula $a^{3}=T^{2}\left(M_{\mathrm{L}}+M_{c}\right)$ can be used if the large axis in a. u., the period in years, and the mass in the masses of the Sun. To deduce it is enough to substitute in the generalized Kepler law data for the Earth - 1 a. u., 1 year, 1 mass of the Sun.

\subsubsection{Dual Star System, Theoretical Problem at III Stage of the Ukrainian National ASTRONOMY OLYMPIAD IN IVANO-FRANKIVSK REGION FOR 10 ${ }^{\mathrm{TH}}-11^{\mathrm{TH}}$ GRADES STUDENTS, 2020}

Based on the data about the close double star system V Arrow to calculate:

a) the maximum angular distance between the stars of V Arrow;

b) estimate the time to merge the stars of the V Arrow system;

c) the time of halving the distance between the stars of V Arrow system.

$\mathrm{D}=7760$ light years, distance

$\mathrm{P}=0.514212053$ days $=12.34$ hours, orbital period

$\mathrm{P}^{*}=-1.734 \times 10^{-7}$ days / year, the rate of change of the orbital period

$\mathrm{M}_{\mathrm{wd}}=0.85 \mathrm{M}$ sun, mass of the white dwarf

$\mathrm{M}_{\mathrm{comp}}=3.3 \mathrm{M}_{\mathrm{sun}}$, the mass of the companion star

$\mathrm{M}^{\cdot}{ }_{2000}=(1-3) 10^{-5} \mathrm{M}$ sun/year - the accretion rate in the year 2000

This task illustrates the methods of analogies and consequences, based on the examples used to illustrate these methods. 


\section{CONCLUSIONS}

The tasks package for any stage of the Ukrainian National Astronomy Olympiad should consist of tasks with different complexity and topics, while the problems should stimulate creative, non-standard thinking and improve the students' analytical skills, which creates certain difficulties in their preparation. Topics such as Kepler's laws, the daily motion of Earth, stellar magnitudes and photometry, telescopes and their characteristics, the redshift and the determination of distances to galaxies (for 11th grade students) etc., are fundamental in astronomy, and should be included in every task package. Because of this, the problem of selecting and completing tasks is further complicated. To solve it, the methods proposed by the team of authors and described in this article can be used, including the method of unusual accent, method of detail, method of neglecting, comprehensive method, method consequences, analogy method and the method of new laws.

\section{REFERENCES}

[1] Maljchenko S. L. Olympiad tasks are from school course of astronomy. Collection of scientific articles "Pedagogical Sciences", 141 (2018), 131-136. Available at: http://enpuir.npu.edu.ua/bitstream/123456789/24886/1/Malchenko.pdf (in Ukrainian)

[2] Pustynnykova I.M., Kucher Ju.O., Stavsjka A.V. Evaluation criteria for solutions of the olympiad problems. Scientific treasury of education of the Donetsk region, 4 (13) (2012), 51-54. Available at: http://irbis-nbuv.gov.ua/cgi-

bin/irbis_nbuv/cgiirbis_64.exe?C21COM=2\&I21DBN=UJRN\&P21DBN=UJRN\&IMAGE_FILE_DOWNL OAD=1\&Image_file_name=PDF/Nsod_2012_4_13.pdf (in Ukrainian)

[3] Sandu M. Astronomy \& Astrophysics. Themes and problems for olympiads and competitions. Editura Didactica si Pedagogica, Bucuresti, 2019.

[4] On approval of the Regulations on Ukrainian National Student Olympiads, tournaments, competitions in academic subjects, competitions-defense of research works, olympiads in special disciplines and competitions of professional skill. Order of MES of Ukraine. 1099 (2011). Available at: https://zakon.rada.gov.ua/laws/show/z1318-11 (in Ukrainian)

[5] About holding the III stage and preparation for the IV stage of the Ukrainian National Astronomy Student Olympiad in the 2019/2020 academic year. Letter of IMZO. 22.1/10-4492 (2019). Available at: https://imzo.gov.ua/2019/12/16/lyst-imzo-vid-13-12-2019-22-1-10-4492-pro-provedennia-iii-etapu-tapidhotovky-do-iv-etapu-vseukrains-koi-uchnivs-koi-olimpiady-z-astronomii-u-2019-2020-navchalnomu-rotsi (in Ukrainian)

[6] Statutes of International Olympiad on Astronomy and Astrophysics. Available at: http://www.ioaastrophysics.org/statutes/

[7] Aniket Sule. A Problems Book in Astronomy and Astrophysics. Cygnus Publishing House, Suceava, Romania, 2014.

[8] Klymyshyn I. A., Krjachko I. P. Astronomy $11^{\text {th }}$ grade. Znannja Ukrajiny, Kyiv, 2002. (in Ukrainian)

Address: Yaroslav Ersteniuk, Ivan Gasyuk, Anna Boryschak, Vasyl Stefanyk Precarpathian National University, 57, Shevchenko Str., Ivano-Frankivsk, 76018, Ukraine;

Petro Yakubovskyi, Ivano-Frankivsk Regional Institute of Postgraduate Teacher Education, 3, Mickiewicz Square, Ivano-Frankivsk, 76018, Ukraine.

E-mail: erstslavik@gmail.com, gasyukim@gmail.com, Cmyaooippo@gmail.com, annabor335@gmail.com

Received: 20.01.2020; revised: 10.03.2020. 
Ерстенюк Ярослав, Гасюк Іван, Якубовський Петро, Борищак Анна. Методика складання та підбору задач для шкільних астрономічних олімпіад на прикладі задач за темою “Закони Кеплера". Журнал Прикарпатського університету імені Василя Стефаника, 7 (1) (2020), 156-165.

На основі багаторічного досвіду організації Всеукраїнських олімпіад III рівня у статті було здійснено спробу сформудювати узагальнені принципи підбору та складання одімпіадних задач 3 астрономії, а також продемонструвати використання описаних принципів на прикладі завдань астрономічних олімпіад в Івано-Франківській області (Україна) протягом останнього п'ятиліття.

Було проведено аналіз особливостей шкільних олімпіад 3 астрономії, мети їхнього проведення, специфіки пакетів задач, зокрема необхідності диференціації за складністю та темами. Характерною рисою олімпіадних завдань є їхня нестандартність, необхідність використання для їх розв'язування незвичних для учнів методів і способів. При цьому такі задачі повинні відповідати інтелектуальному розвитку учасників змагання, а хід розв'язку повинен бути доступним для розуміння. Це означує проблему творення таких завдань, якій в даній статті була приділена основна увага. Зокрема, на основі аналізу процесу укладання олімпіадних астрономічних задач, які були запропоновані учням в минулі роки на обласному етапі учнівської олімпіади, було виокремлено, систематизовано і охарактеризовано методи їхнього укладання. Кожен метод містить детальне пояснення, аргументацію доцільності його використання та приклади, як аналітичного, так i практичного характеру. Для наочності було проаналізовано одімпіадні задачі та описано методи, використані при їхньому творенні, за темою “закони Кеплера", яка є однією з фундаментальних у рамках шкільного вивчення астрономії, що одночасно визначає як необхідність вкдючення таких завдань в програму олімпіади, так і складність їх вибору і створення, адже тема достатньо вузька і при цьому якісно висвітлена в різноманітних підручниках і збірниках задач.

Кдючові слова: нестандартні задачі, Всеукраїнська учнівська олімпіада з астрономії, закони Кеплера. 